\title{
Plea Bargaining dalam Sistem Peradilan Pidana di Beberapa Negara
}

\author{
Nella Octaviany Siregar ${ }^{1}$ \\ Fakultas Hukum Universitas Batanghari \\ Email: nella.octaviany.siregar@unbari.ac.id
}

\begin{abstract}
Abstrak. Plea Bargaining System secara luas diartikan sebagai sebuah pernyataan bersalah dari seorang tersangka maupun terdakwa. Plea Bargaining banyak dianut di negara-negara yang menganut sistem hukum Common Law. Plea Bargaining yang dikembangkan dalam sistem hukum "common law" ini telah mengilhami munculnya "mediasi" dalam praktik peradilan berdasarkan hukum pidana di Belanda dan Prancis, yang dikenal dengan "transactie". Plea Bargaining dikategorikan sebagai sebuah upaya penyelesaian di luar sidang dan penggunanya juga didasari oleh alasan-alasan tertentu. Bahkan dalam upaya pembaharuan hukum acara peradilan pidana di Indonesia, telah juga mengambil konsep dasar plea bargaining yang diadopsi dalam RUU KUHAP dengan konsep "Jalur Khusus". Bahwa dengan hadirnya konsep "Jalur Khusus" ini, juga menjadi perhatian apabila melihat dapat diberlakukannya kembali pengakuan bersalah terdakwa sebagai dasar hakim menjatuhkan putusan. Tujuan tulisan ini untuk mengetahui, menganalisa plea bargaining di beberapa negara. Tipe penelitian yang digunakan adalah penelitian yuridis normatif, menggunakan pendekatan konseptual, pendekatan perbandingan, dan pendekatan sejarah.
\end{abstract}

Kata kunci: Plea Bargain, Sistem Peradilan Pidana

Abstract. Plea Bargaining System is widely interpreted as a statement of guilt of a suspect or defendant. Plea Bargaining practised in many countries that have embraced the Common Law legal system. Plea Bargaining that was developed in the common law "legal system" has inspired the emergence of "mediation" in the practice of the judiciary based on the criminal law in the Netherlands and France, known as "transactie". Plea Bargaining is categorized as a settling outside the hearing and their users is also based on specific reasons. Even in the renewal of law criminal justice events in Indonesia, has also picked up the basic concept of plea bargaining that was adopted in the RUU KUHAP with the concept of "Jalur Khusus". That with the presence of the concept of "Jalur Khusus", is also a concern when viewed can enactment back recognition of guilt of the defendant as the basis of the judge's verdict is dropping. The purpose of this paper is to find out, analyze the plea bargaining in some countries. The type of research used is the juridical normative research, using a conceptual approach, comparative approach, historical approach.

Keywords: Plea Bargain, Sistem Peradilan Pidana

\section{PENDAHULUAN}

Di dalam perkara tindak pidana dalam menetapkan seseorang menjadi tersangka kemudian menjadi terdakwa dan memperoleh hukuman sesuai perbuatan tindak pidana yang dilakukan melalui proses yang secara garis besar melibatkan tiga lembaga yaitu kepolisian, kejaksaan, dan kehakiman. Proses secara umum yaitu penyidikan dilakukan kepolisian dan penuntutan dilakukan oleh kejaksaan.

Perkembangan system peradilan pidana di beberapa negara penganut sistem hukum Common Law dan Civil Law masih belum banyak mengalami perubahan dari karakteristk tradisional yang sering dibedakan dalam model "due process" dan "crime control". ${ }^{2}$ Perubahan signifikan dalam penerapan kedua model tersebut di beberapa negara maju baik yang menganut sistem hukum "civil law" dan "common law" terbatas pada deviasi terhadap proses peradilan pidana sistem mediasi sebagaimana dipraktikkan di dalam KUHAP Belanda dan KUHAP Perancis, dengan ketentuan mengenai "transactie"3

Plea Bargaining System secara luas diartikan sebagai sebuah pernyataan bersalah dari seorang tersangka maupun terdakwa. Plea Bargaining banyak dianut di negara-negara yang menganut sistem hukum Common Law. Plea Bargaining yang dikembangkan dalam sistem hukum "common law" ini telah mengilhami munculnya "mediasi" dalam praktik peradilan berdasarkan hukum pidana di Belanda dan

\footnotetext{
${ }^{1}$ Dosen Fakultas Hukum Universitas Batanghari

2 Herbert Packer, "The Limits of the Criminal Sanction" dalam Romli Atmasasmita, Sistem Peradilan Kontemporer, Jakarta: Kencana Prenadamedia Group, 2011., hal. ix

${ }^{3}$ Dutch Penal Code (1818) dan KUHAP Perancis (2000) dalam Ibid
} 
Prancis, yang dikenal dengan "transactie". Plea Bargaining dikategorikan sebagai sebuah upaya penyelesaian di luar sidang dan penggunanya juga didasari oleh alasan-alasan tertentu.

Dalam praktek peradilan pidana yang berlaku di negara common law, khususnya di Amerika, bahwa dikenal Plea bargaining, yang diketahui sebagai praktek penanganan perkara pidana, dimana antara pihak penuntut umum (jaksa) dan terdakwa atau penasehat hukumnya telah terjadi perundingan/negosiasi tentang jenis kejahatan yang akan didakwakan dan ancaman hukuman yang akan dituntut dimuka persidangan kelak. Pengakuan bersalah secara sukarela dari terdakwa menjadi patokan bagi penuntut umum untuk menentukan ancaman pidana yang akan diajukan dimuka sidang. Maka dengan adanya konsep ini, sebuah peradilan pidana yang seharusnya memerlukan proses yang cukup panjang, menjadi lebih efisien dan cepat. Hakim dalam sistem ini hanya menjatuhkan pidana sebagaimana hasil perundingan yang telah disepakati oleh penunut umum dan terdakwa.

Konsep Plea Bargaining juga diberlakukan di negara-negara civil law, seperti Jerman, Rusia, Georgia, Prancis, Belanda. Bahkan dalam upaya pembaharuan hukum acara peradilan pidana di Indonesia, telah juga mengambil konsep dasar plea bargaining yang diadopsi dalam RUU KUHAP dengan konsep "Jalur Khusus". Bahwa dengan hadirnya konsep "Jalur Khusus" ini, juga menjadi perhatian apabila melihat dapat diberlakukannya kembali pengakuan bersalah terdakwa sebagai dasar hakim menjatuhkan putusan. ${ }^{4}$

Tidak diketahui secara tepat kapan sistem ini lahir. Hanya ada pendapat, bahwa sistem ini telah lahir dan berkembang sepanjang sejarah "common law system" menguasai Daratan Amerika. Akan tetapi, kemudian ada pula pendapat yang mengatakan bahwa sistem tersebut tidak dikenal pada saat itu. Dan akhirnya dapat diketahui, bahwa adanya perbedaan pendapat di atas disebabkan adanya perbedaan penafsiran mengenai sistem tersebut dan adanya praktik penghapusan hukuman yang sangat kejam di masa lampau melalui tindakan sepihak serta kompromi dengan maksud memperoleh informasi lebih lanjut dari si tertuduh. $^{5}$

Alschuler mengemukakan bahwa semula "plea bargaining" ini muncul pada pertengahan abad ke-19, dan kemudian dikenal dalam bentuknya seperti sekarang ini. Pada akhir abad ke-19 dan awal abad ke-20, sistem ini sangat berperan dalam mengatasi kesulitan menangani perkara pidana. Bahkan pada sekitar tahun 1930, pengadilan di Amerika Serikat sangat bergantung pada sistem ini.

Pada tahun 1958, Mahkamah Agung Amerika Serikat pernah menyatakan bahwa praktik plea bargaining adalah illegal. Akan tetapi atas keberatan Dewan Kehakiman kehendak tersebut tidak dilaksanakan. Bahkan pada akhirnya pada tahun 1970, Mahkamah Agung menyatakan pendapatnya bahwa "plea bargaining adalah melekat dalam hukum pidana dan merupakan administrasi". ${ }^{6}$ Hingga saat ini tidak ada perhatian yang sungguh-sungguh untuk menghapuskan sistem ini, oleh karena dengan adanya sistem tersebut tampaknya telah memperoleh suatu "fair trial" dan "accuracy" dalam penanganan perkara pidana.

Pengertian Plea Bargaining dalam Black's Law Dictionary adalah: ${ }^{7}$

"Suatu kesepakatan perundingan antara penuntut umum dan terdakwa dimana terdakwa mengaku bersalah atas tindak pidana tertentu atau atas lebih dari satu tuntutan dengan imbalan dari penuntut umum untuk menuntut hukuman ringan atau membebaskan dari tuntutan atas tindak pidana lainnya”

Timothy Lynch menyatakan pandangannya tentang Plea Bargaining, bahwa:

"Plea Bargaining terdiri kesepakatan (formal maupun informal) antara terdakwa dan jaksa penuntut umum. Jaksa Penuntut umum biasanya setuju dengan mengurangi hukuman penjara yang dalam hal ini mengesampingkan hak konstitusional non self in crimination dan hak diadili dari terdakwa. ${ }^{8}$

4 Aby Maulana, "Konsep Pengakuan Bersalah Terdakwa Pada "Jalur Khusus" Menurut RUU KUHAP dan Perbandingannya dengan Praktek Plea Bargaining Di Beberapa Negara”, Jurnal Cita Hukum Vol 3. (Juni 2015 ), hal 43.

5 Albert Alschuler, Plea Bargaining and Its History, Columbia Law Review (Vol. 79:1), 1979, p. 4 dalam Romli Atmasasmita, Op.Cit,. Hal. 118

${ }^{6}$ Brady v. United States, 397 US. 742 (1970) dalam Ibid

${ }^{7}$ Black's Law Dictionary With Pronounciations, Sixth Edition (Boston: St. Paul Minn West Group. 1990). P.1152

${ }^{8}$ Timothi Lynch, The Case Againts Plea Bargaining (Cato Institute Project on Criminal Justice, 2003), h. 1. 
Dengan demikian, dalam mekanisme sistem plea bargaining, apabila telah terjadi kesepakatan antara penuntut umum dengan tersangka/terdakwa, maka akan dapat mengesampingkan hak terdakwa atas non self in crimination dan berimplikasi adanya pemberhentian proses peradilan selanjutnya.

Selain itu, menurut Eko Budi S, dalam jurnalnya tentang kebijakan hukum terhadap tindak pidana penangkapan ikan secara ilegal di perairan Indonesia menyatakan bahwa perumusan hukum pidana itu antara lain: ${ }^{9}$

a). Hukum Pidana adalah bagian dari keseluruhan hukum yang berlaku di suatu Negara.

b). Perbuatan yang oleh hukum pidana dilarang dan diancam dengan pidana.

c). Hukum pidana menentukan perbuatan mana yang dipandang sebagai perbuatan pidana.

d). Barang siapa melakukan perbuatan pidana diancam dengan pidana.

e). Hukum pidana mengatur tentang pertanggungjawaban hukum pidana (criminal liability/ criminal responsibility).

f). Beberapa pendapat tentang pengertian hukum pidana.

g). Hal-hal yang perlu ditegaskan sehubungan pengertian kita kepada hukum pidana.

Oleh karena itu, apabila melihat dari rumusan pidana di atas, maka menggunakan hukum pidana sangat jelas bahwa siapa yang bersalah akan mendapat hukuman atas perbuatan yag dilakukannya.

Kemudian menurut Carolyn E. Demarest, terdapat hal yang menguntungkan bagi Penuntut Umum maupun Terdakwa dalam mekanisme Plea Bargaining: ${ }^{10}$

"Mekanisme Plea Bargain diyakini membawa keuntungan, baik untuk terdakwa maupun untuk masyarakat. Keuntungan bagi terdakwa adalah dirinya bersama penuntut umum bisa menegosiasikan hukuman yang pantas baginya. Masyarakat diuntungkan karena mekanisme ini akan menghemat biaya pemeriksaan di pengadilan, dimana terdakwa mengakui perbuatannya dan tetap akan mendapatkan hukuman. Meskipun hukuman yang diberikan rata-rata lebih sedikit dari apa yang akan diputus hakim jika melalui proses pengadilan konvensional, namun disisi lain mekanisme ini dapat memberikan efek terhadap proses peradilan pidana karena penuntut umum mempunyai waktu lebih banyak dan bisa menangani lebih banyak perkara."

John Wesley Hall, Jr. memberikan pemaparan bahwa Plea bargaining dilakukan dalam rangka menyelesaikan perkara pidana tanpa melalui peradilan, bahwa dalam Plea Bargaining bukanlah suatu negosiasi yang direkayasa melainkan harus mengutamakan kejujuran atas fakta-fakta yang terjadi:

"Jika sifat dan keadaan dari kasus tersebut menjamin itu, penuntut umum harus mengeksplorasi kemungkinan bahwa kasus tersebut dapat dialihkan dari proses pidana. Jaksa juga memiliki sebuah tugas dalam menjalankan kebijaksanaan penuntutan mereka. Kedua belah pihak untuk diskusi pembelaan memiliki kewajiban keterbukaan dan keterusterangan, dan penuntut umum" tidak boleh secara sadar membuat pernyataan palsu mengenai bukti dalam proses diskusi pembelaan dengan penasehat hukum lawan.

Beberapa batasan mengenai plea bargaining yaitu: ${ }^{11}$

1. Bahwa "plea bargaining" ini pada hakikatnya merupakan suatu negosiasi antara pihak penuntut umum dengan tertuduh atau pembelanya;

2. Motivasi negosiasi tersebut yang paling utama ialah untuk mempercepat proses penanganan perkara pidana;

3. Sifat negosiasi harus dilandaskan pada "kesukarelaan" tertuduh untuk mengakui kesalahannya dan kesediaan penuntut umum memberikan ancaman hukuman yang dikehendaki tertuduh atau pembelanya;

4. Keikutsertaan hakim sebagai wasit yang tidak memihak dalam negosiasi dimaksud tidak diperkenankan.

\footnotetext{
${ }^{9}$ Eko Budi S, Kebijakan Hukum Terhadap Tindak Pidana Penangkapan Ikan Secara Ilegal Di Perairan Indonesia, Jurnal Wajah Hukum Volume 2 Nomor 2, (Oktober 2018) : hal 204.

${ }^{10}$ Carolyn E. Damarest dikutip dalam Dimas Prasidi, Plea-Bargaining: Sebuah Jalan Permisif bagi Keadilan, diakses pada 20 Desember 2018

11 Romli Atmasasmita, Op.Cit,. Hal. 127-128
} 


\section{METODE PENELITIAN}

Tipe penelitian yang digunakan adalah penelitian yuridis normatif, penelitian ini menggunakan "pendekatan konseptual, pendekatan perbandingan, dan pendekatan sejarah".

Bahan-bahan hukum yang telah diperoleh, diinventarisasi dan diidentifikasi untuk digunakan sebagai bahan dalam menganalisis pokok permasalahan dalam penelitian ini. Identifikasi bahan hukum baik primer, sekunder, maupun tertier dilakukan secara kritis, logis, dan sistematis, hal ini dilakukan untuk mempermudah proses pengolahan data hukum tersebut, dengan demikian bahan hukum akan disusun dan digolongkan menurut bentuk, jenis dan tingkatnya. Adapun bahan hukum yang digunakan dalam penelitian ini adalah:

a. Bahan hukum primer terdiri dari buku-buku tentang Plea Bargain.

b. Bahan hukum sekunder yaitu bahan hukum yang dapat memberikan penjelasan mengenai bahan hukum primer, seperti: hasil-hasil penelitian, hasil karya dari kalangan hukum baik berbentuk jurnal hukum, makalah dan lain-lain.

c. Bahan hukum tertier yakni bahan hukum yang dapat memberikan petunjuk maupun penjelasan terhadap bahan hukum primer dan sekunder.Contohnya: kamus, ensiklopedia, dan lain-lain

\section{HASIL DAN PEMBAHASAN}

Beberapa Negara yang telah mengadopsi dan menerapkan plea bargaining dalam system peradilan pidana di Negaranya masing-masing, adalah sebagai berikut:

\section{Plea Bargaining di Kanada}

Selama bertahun-tahun, plea bargaining telah menjadi salah satu hal yang paling kontroversial dalam praktek system peradilan pidana di Kanada. Plea Bargaining adalah prosedur singkat dan lengkap yang menggambarkan berbagai kemungkinan adanya tawar menawar atau negosiasi dalam system peradilan pidana Kanada. Polisi, Jaksa, dan Penasehat hukum akan terlibat pada diskusi sederhana dengan cara negosiasi yang menghasilkan kesepakatan, yang dianggap akan mengikat para pihak. Bahkan Verdun-Jones dan Hatch menyatakan: ${ }^{12}$

"Tidak diragukan lagi, para anggota peradilan Kanada kini telah menerima kenyataan bahwa permohonan tawar (plea bargaining) memainkan peran penting dalam administrasi yang efisien keadilan dan telah dipertahankan dengan merangkul kebijakan hukuman yang secara tidak langsung membangun pengaruh terhadap kesepakatan yang dibentuk oleh penuntut umum dan penasehat hukum."

Terdapat 3 kategori dalam plea bargaining pada system peradilan pidana Kanada, yaitu:

a. Charge Bargaining (tawar menawar dakwaan)

1. Mengurangi dakwaan menjadi tindak pidana lebih ringan;

2. Menarik atau meninggalkan dakwaan yang lain atau sepakat untuk tidak menuntut dengan dakwaan lain yang memungkinkan;

3. Sepakat untuk tidak mendakwa teman atau keluarga yang terlibat sebagai tersangka;

4. Sepakat untuk menarik dakwaan dari tersangka dan mengarahkan pada perdamaian.

b. Sentence Bargaining (tawar menawar hukuman)

1. Sepakat untuk melanjutkan proses tanpa melalui pengadilan;

2. Sepakat untuk membuat rekomendasi hukuman tertentu;

3. Sepakat tidak akan menentang rekomendasi hukuman yang telah diajukan penasehat hukum;

4. Sepakat untuk menyetujui bersama-sama atas hukuman yang diajukan;

5. Sepakat untuk tidak mengajukan banding atas hukuman yang telah dijatuhkan;

6. Sepakat untuk tidak akan mengajukan hukuman yang lebih berat;

7. Sepakat untuk tidak memberlakukan pada sidang pengadilan ketika diketahui bahwa tersangka berbahaya;

8. Sepakat untuk membuat penjara menjadi tempat pengobatan/pemulihan, dan lain-lain;

9. Sepakat untuk mengatur hukuman tertentu sebelum hakim menjatuhkan putusan tertentu

c. Fact Bargaining (tawar menawar fakta/bukti)

12 http://www.justice.gc.ca/eng/rp-pr/cj-jp/victim/rr02_5/p3_3.html, diakses pada 22 Desember 2018 
1. Sepakat untuk tidak mengemukakan informasi yang merugikan selama pemeriksaan sidang;

2. Berjanji untuk tidak menyebutkan keadaan dari pelanggaran yang dapat ditafsirkan oleh hakim sebagai faktor yang memberatkan. ${ }^{13}$

Berbagai bentuk yang dapat disepakati melalui plea bargaining dalam system peradilan pidana Kanada tidak hanya berkenaan dengan kesepakatan menentukan banyak atau sedikitnya hukuman, tetapi juga mencakup ranah pendakwaan/penuntutan dan juga mengenai bukti-bukti. Richard Hewson mengemukakan:

"Di Kanada, pengadilan selalu memiliki putusan akhir berkaitan dengan hukuman. Namun demikian, plea bargaining telah diterima sebagai bagian dari system peradilan pidana meskipun hakim dan pengacara/penuntut umum kerajaan sering enggan menyebutkan seperti itu. Dalam kebanyakan proses pidana Kanada, pengacara/penuntut umum kerajaan memiliki kemampuan untuk merekomendasi-kan hukuman yang lebih ringan dari itu akan mencari menyusul vonis bersalah dalam pertukaran untuk pengakuan bersalah. Seperti yurisdiksi common law lainnya, pengacara/penuntut umum kerajaan juga bias menyetujui untuk menarik beberapa dakwaan terhadap terdakwa dalam pertukaran untuk pengakuan bersalah. Hal ini telah menjadi prosedur standar untuk pelanggaran tertentu seperti gangguan mengemudi. Perhatikan bahwa dalam kasus pelanggaran hybrid, pengacara/ penuntut umum kerajaan harus membuat keputusan yang mengikat, apakah untuk melanjutkan atau dengan dakwaan sebelum terdakwa membuat permohonan. Jika pengacara/penuntut umum kerajaan memilih untuk melanjutkan dan terdakwa kemudian mengaku tidak bersalah, kerajaan tidak dapat mengubah putusan. Oleh karena itu, pengacara/penuntut umum kerajaan tidak dalam posisi menawarkan untuk melanjutkan pertukaran untuk pengakuan bersalah.

Praktek plea bargaining yang diterapkan di Kanada, dapat dikatakan tidak berbeda dengan plea bargaining yang diterapkan di Amerika Serikat. Satu hal yang diatur secara komprehensif dalam system peradilan pidana Kanada yakni adanya "partisipasi korban", sehingga plea bargaining dapat diberlakukan tidak hanya semata-mata menguntungkan terdakwa, tetapi juga dapat memuaskan kepentingan korban.

\section{Plea Bargaining di Inggris dan Wales}

Praktek plea bargaining dalam system peradilan pidana di Inggris dan Wales telah membawa pengaruh yang besar, guna meningkatkan angka penyelesaian perkara dengan cepat dan efisien. Hal lainnya, adalah menghindari adanya case load yang seringkali mengganggu kinerja jaksa maupun hakim dalam memutus perkara.

Plea bargaining adalah salah satu yang terutama digunakan oleh jaksa untuk mengamankan kesaksian seseorang dituduh melakukan kejahatan terhadap persekongkolan yang telah didakwa dengan kejahatan yang lebih serius. Dalam banyak keadaan seorang individu akan dapat menegosiasikan hukuman dikurangi dengan mengaku bersalah atas tuduhan yang lebih ringan dalam pertukaran untuk menyetujui kondisi tertentu yang akan kerap beragam tergantung situasi kasus. Plea bargaining dalam situasi ini akan sering terjadi ketika bukti terhadap seorang individu yang sangat kuat. ${ }^{14}$

"Plea bargaining dalam Magistrates Court hanya diperbolehkan sejauh bahwa jaksa dan terdakwa dapat setuju bahwa terdakwa akan mengaku bersalah atas beberapa tuduhan dan jaksa akan turun sisanya. Namun, meskipun hal ini tidak melakukan tawar-menawar pembelaan, dalam kasuskasus sebelum Crown Court, terdakwa dapat meminta indikasi dari hakim hukuman maksimal kemungkinan yang akan dikenakan harus terdakwa memutuskan untuk mengaku bersalah. Dalam kasus pelanggaran campuran di Inggris dan Wales, keputusan apakah akan menangani kasus di Magistrates Court atau Crown Court tidak dibuat oleh hakim sampai setelah permohonan telah dimasukkan. Seorang terdakwa dengan demikian tidak dapat mengaku bersalah dalam pertukaran

\footnotetext{
${ }^{13}$ http://www.justice.gc.ca/eng/rp-pr/cj-jp/victim/rr02_5/p3.html, diakses pada tanggal 22 Desember 2018

${ }^{14} \mathrm{http} / / /$ www.inbrief.co.uk/court-proceedings/plea-bargaining.htm diakses pada tanggal 23 Desember 2018
} 
untuk memiliki kasus ditangani di Magistrates Court (yang memiliki kekuatan hukuman yang lebih rendah" 15

Oleh karena itu, plea bargaining dengan sistem hukum yang serupa dengan Amerika Serikat, dapat dikatakan tidak terlalu sulit dalam penerapannya. Setidaknya terdapat dua (2) bentuk plea bargaining yang ada pada sistem peradilan pidana Inggris, yakni:

1. Tawar menawar pada dakwaan, jika terdakwa mengaku maka akan dikurangi dakwaan/tuduhan pada suatu kejahatan, dalam kebanyakan kasus, akan dipilih satu dari dua dakwaan;

2. Tawar menawar hukuman, dimana ketika hakim menyampaikan kepada terdakwa tentang hukuman yang akan dijatuhkan namun terdakwa mengajukan pengakuan bersalah, maka akan diringankan dibandingkan ia menolak untuk mengaku.

\section{Plea Bargaining di Perancis}

Bahwa plea bargaining di Perancis diperkenalkan sejak tahun 2004, dan telah menuai berbagai argumentasi dan perdebatan karena dianggap dapat mencederai asas praduga tak bersalah (presumption of innocence) dan juga hak untuk diadili pada peradilan yang adil dan wajar (due process of law). Wikipedia menjelaskan: ${ }^{16}$

"Pengenalan bentuk terbatas permohonan tawar (comparation sur reconnaissance préalable de culpabilité atau CRPC, sering diringkas sebagai plaider coupable) pada tahun 2004 sangat kontroversial di Perancis.Dalam sistem ini, jaksa penuntut umum bisa mengusulkan kepada tersangka kejahatan yang hukumannya relatif kecil tidak melebihi satu tahun penjara, kesepakatan, jika diterima, harus diterima oleh hakim. Lawan, biasanya pengacara dan partai politik sayap kiri, berpendapat bahwa permohonan tawar akan sangat melanggar hak pembelaan, hak konstitusional lama dari praduga tak bersalah, hak-hak tersangka dalam tahanan polisi, dan hak untuk mendapatkan pengadilan yang adil”

Robert Badinter mengemukakan resiko apabila plea bargaining di berlakukan di Perancis, yakni akan berbahaya apabila sistem ini akan dimanfaatkan oleh terdakwa untuk menghindari hukumna yang lebih berat.

"Misalnya, Robert Badinter berpendapat bahwa permohonan tawar akan memberikan terlalu banyak kekuasaan kepada jaksa penuntut umum dan akan mendorong terdakwa menerima hukuman hanya untuk menghindari risiko hukuman yang lebih besar di pengadilan, bahkan jika mereka tidak benarbenar layak mendapatkannya. Hanya sebagian kecil kasus pidana diselesaikan dengan metode bahwa: pada tahun 2009, 77.500 keluar dari 673.700 atau 11,5\% dari keputusan oleh pengadilan pemasyarakatan"

Stephen C. Thaman menyatakan: Di perancis, Penuntut umum akan membuat rekomendasi hukuman setelah adanya pengakuan bersalah terdakwa. ${ }^{17}$ Tujuan mempercepat peradilan menjadi lebih efisien juga dapat tercatat pada tahun 2009, sekitar 77.500 kasus (11,5\%) selesai melalui plea bargaining dari keseluruhan 673.700 kasus.

\section{Plea Bargaining di Georgia}

Plea bargaining mulai masuk pada sistem peradilan pidana Georgia sejak tahun 2004. Pada prakteknya, plea bargaining di Georgia mirip dengan plea bargaining yang dipraktekkan di Amerika Serikat

${ }^{15}$ R.V. Goodyear, Code for Crown Prosecutors - Accepting Guilty Pleas At the Crown Court-Court Stage-

Enforcement Guide (England \& Wales), dalam http://en.wikipedia.org/wiki/Plea_bargain, diakses pada 23 Desember 2018

${ }^{16}$ Les chiffres-clés de la Justice, French Ministry of Justice, dalam http://en.wikipedia. org/wiki/Plea_bargain diakses pada 24 Desember 2018

${ }^{17}$ Stephen C. Thaman, Plea-Bargaining, Negotiating Confessions and Consensual Resolution of Criminal Cases, h. 31 


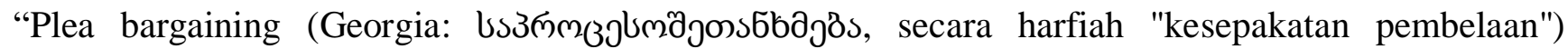
diperkenalkan di Georgia pada tahun 2004. Substansi permohonan tawar Georgia mirip dengan Amerika Serikat dan yurisdiksi hukum umum lainnya. Sebuah tawar- menawar pembelaan, juga disebut kesepakatan pembelaan atau permohonan dinegosiasikan, adalah cara alternatif dan konsensual penyelesaian kasus pidana. Sebuah kesepakatan pembelaan berarti penyelesaian kasus tanpa sidang utama saat terdakwa setuju untuk mengaku bersalah dalam pertukaran untuk biaya yang lebih rendah atau untuk hukuman yang lebih ringan dan/atau pemberhentian dakwaan tertentu.(Pasal 209 KUHAP Georgia)"18

Kesepakatan yang dihasilkan melalui proses plea bargaining mengharuskan seorang tersangka/terdakwa mengaku bersalah, dan ditukar dengan peringanan pidana. Jaksa sebagai penegak hukum, memiliki tugas mewakili kepentingan korban dalam melakukan penuntutan.Dikaitkan dengan berlakunya plea bargaining, Jaksa dalam melakukan negosiasi dengan terdakwa dan penasehat hukumnya, diharuskan memperhatikan kepentingan korban, terlebih lagi bertujuan memulihkan kerugian yang telah diderita korban.

"Perjanjian permohonan disimpulkan antara pihak jaksa dan terdakwa.Meskipun fakta bahwa korban bukan pihak ke kasus pidana dan jaksa bukan merupakan alat bagi korban untuk balas dendam kepada pelaku, sikap korban sehubungan dengan perjanjian pembelaan masih penting. Menurut Pasal 217 dari Kode Prosedur Pidana Georgia, jaksa wajib berkonsultasi dengan korban sebelum menyimpulkan kesepakatan pembelaan dan memberitahukan / padanya tentang hal ini. Selain itu, dalam Pedoman Kejaksaan Georgia, jaksa wajib mempertimbangkan kepentingan korban dan sebagai aturan menyimpulkan perjanjian pembelaan setelah kerugian dipulihkan"19

\section{Plea Bargaining di Polandia}

Polandia mempraktekkan plea bargaining yang berbeda dari bentuk aslinya di Amerika Serikat, karena dalam negosiasi plea bargaining mengharuskan adanya keterlibatan korban.Persetujuan korban menjadi salah satu unsur yang utama, dan sangat menentukan terjadinya kesepakatan. ${ }^{20}$

Polandia juga mengadopsi plea bargaining, yang hanya berlaku untuk kejahatan kecil (dengan ancaman tidak lebih dari 10 tahun penjara).Prosedur ini disebut "penyerahan sukarela untuk hukuman" dan memungkinkan pengadilan untuk menjatuhkan putusandengan menyetujui tanpa meninjau bukti, secara signifikan dapat mewujudkan persidangan lebih cepat. Ada beberapa kondisi tertentu yang harus dipenuhi secara simultan:

1. terdakwa mengaku bersalah dan mengusulkan hukuman,

2. jaksa setuju,

3. korban setuju,

4. pengadilan setuju.

Namun, pengadilan dapat menolak ketentuan perjanjian permohonan diajukan (bahkan jika sudah disepakati antara terdakwa, korban dan jaksa) dan menyarankan perubahan (tidak tertentu melainkan umum). Jika terdakwa menerima saran ini dan mengubah proposisi hukumannya, pengadilan menyetujuinya dan melewati putusan sesuai dengan kesepakatan pembelaan. Meskipun perjanjian tersebut, semua pihak pengadilan: penuntutan, terdakwa dan korban sebagai jaksa tambahan (di Polandia, korban dapat menyatakan bahwa ia ingin bertindak sebagai "jaksa tambahan" dan karenanya memperoleh hak yang sama dengan resmi JPU) - memiliki hak untuk mengajukan banding.

18 Department Publications-Ministry of Justice of Georgia dalam http://en.wikipedia.org/ wiki/Plea_bargain, diakses pada 24 Desember 2018

${ }^{19}$ Ibid

${ }^{20}$ Plea bargaining in Poland criminal procedures, dalam http://en.wikipedia.org/wiki/Plea_bargain, diakses pada tanggal 25 Desember 2018 


\section{Plea Bargaining di Italia}

Di Italia, plea bargaining hanya diperkenankan terhadap pelaku tindak pidana yang ancaman pidananya tidak lebih dari 5 (lima) tahun penjara. Apabila tersangka pengaku bersalah, maka akan dikuranggi hukumannya 1/3. ItalianCriminal Trial dijabarkan bahwa: ${ }^{21}$

Plea bargaining (patteggiamento) ini tidak tentang tawar menawar dakwaan, tapi tentang putusan atau hukuman, dikurangi sepertiga. Ketika terdakwa menganggap bahwa hukuman yang akan konkret, ancamannya tidak lebih dari lima tahun penjara (atau bahwa itu hanya akan menjadi denda), terdakwa dapat pembelaan tawar-menawar dengan jaksa. Terdakwa dihargai dengan pengurangan pada hukuman dan memiliki kelebihan lainnya (seperti bahwa terdakwa tidak membayar biaya pada persidangan tersebut).Terdakwa harus menerima untuk mengaku bersalah atas dakwaan (bahkan jika plea bargaining menghasilkan putusan yang memiliki beberapa hal tertentu dalam proses kompensasi lebih lanjut), tidak peduli seberapa serius dakwaan itu.Kadang- kadang, jaksa setuju untuk mengurangi dakwaan atau untuk menjatuhkan beberapa beberapa dakwaan dalam pertukaran untuk pengakuan bersalah terdakwa, sering untuk pelanggaran yang lebih rendah.Ketika antara jaksa dan terdakwa telah mencapai kesepakatan, usulan tersebut diajukan kepada hakim, selanjutnya hakim dapat menolak atau menerima permohonan tawar.

Dengan melihat perbandingan plea bargaining pada negara-negara di atas, dapat diketahui bahwa, plea bargaining yang diadopsi negara-negara tersebut tidak selalu sama dengan yang berlaku di Amerika. Namun, secara mendasar pelaksanaan teknis dalam plea bargaining system ini menimbulkan beberapa masalah. Zimring dan Frase menyebutkan beberapa masalah tersebut sebagai berikut: ${ }^{22}$

1. Sistem permintaan keringanan hukuman dalam prakteknya biasanya menjadikan laporan dan penyidikan lainnya pada latar belakang tertuduh tidak efektif

2. Informalitas serta berbagai variasi dalam praktek di antara para jaksa dan Hakim sidang pengadilan mengenai permintaan keringanan hukuman menyebabkan kebingungan serta rasa ketidakadilan di antara terdakwa

3. Sistem permintaan keringanan hukum menjadikan penjahat professional memanfaatkan sepenuhnya untuk rnernperoleh keringanan hukuman daripada terdakwa yang iniskin yang tidak mampu membayar ahli hukum

4. Terdakwa yang tidak bersalah dapat dijadikan bersalah karena kekhawatiran bahwa dia akan dihukum lebih berat lagi jika dia divonis sesudah sidang peradilan atau dia merusak publisitas karena tuduhan yang sangat tidak menyenangkan

\section{SIMPULAN}

Berikut beberapa kesimpulan yang dapat ditarik oleh penulis yaitu:

1. Di beberapa negara yang mengatur praktek plea bargaining mengatur batas yang berbeda-beda, misalnya:

a. Amerika Serikat, Canada, Inggris dan Wales: dapat digunakan untuk mengadili jenis tindak pidana apapun, tidak terbatas pada lamanya ancaman pidana;

b. Polandia: tindak pidana yang ancaman pidananya tidak lebih dari 10 tahun penjara;

c. Italia: tindak pidana yang ancaman pidananya tidak lebih dari 5 tahun penjara;

2. Plea bargaining dilakukan di luar sidang atau sebelum proses perkara masuk ke pengadilan, yang dalam hal ini Jaksa diperkenankan melakukan negosiasi untuk menentukan berat ringannya pidana atau tuntutan tindak pidana yang akan ditujukan kepada terdakwa. Dalam praktek plea bargaining, kesepakatan untuk mengakui kesalahan yang diperoleh di luar sidang itulah yang menjadi dasar bagi hakim memutus perkara.

${ }^{21}$ How does the italian criminal trial work? Dalam http://en.wikipedia.org/wiki/ Plea_bargain, diakses pada 25 Desember 2018

${ }^{22}$ Zimring dan R. Frase dalam Romli Atmasasmita, Sistem Peradilan Pidana Perspektif Eksistensialisme dan Abolisionisme (Bandung: Binacipta, 1996), h. 113-114. 


\section{DAFTAR PUSTAKA}

\section{Buku}

Atmasasmita, Romli, Sistem Peradilan Pidana Kontemporer (Jakarta: Prenada Media, 2011)

Black's Law Dictionary With Pronounciations, Sixth Edition (Boston: St. Paul. Minn West Group, 1990) Charleton SC, Peter dan Paul Anthony McDermott BL, Constitutional Implicatons of Plea Bargain (Bar Riview, 2000)

Hamzah, Andi, et.al., Naskah Akademik Rancangan Kitab Undang-Undang Hukum Acara Pidana (Jakarta: 2011)

Eko Budi S, Kebijakan Hukum Terhadap Tindak Pidana Penangkapan Ikan Secara Ilegal Di Perairan Indonesia, Jurnal Wajah Hukum Volume 2 Nomor 2, (Oktober 2018)

Lynch, Timothi The Case Againts Plea Bargaining (Cato Institute Project on Criminal Justice, 2003)

Thaman, Stephen C. Plea-Bargaining, Negotiating Confessions and Consensual Resolution of Criminal Cases

\section{Peraturan Perundang-Undangan}

Dutch Penal Code (1818)

KUHAP Perancis (2000)

\section{Jurnal}

Aby Maulana, "Konsep Pengakuan Bersalah Terdakwa Pada "Jalur Khusus" Menurut RUU KUHAP dan Perbandingannya dengan Praktek Plea Bargaining Di Beberapa Negara", Jurnal Cita Hukum Vol 3. (Juni 2015)

\section{Internet}

http://en.wikipedia.org/wiki/ Plea_bargain

http://www.inbrief.co.uk/court-proceedings/plea-bargaining.htm

http://www.justice.gc.ca/eng/rp-pr/cj-jp/victim/rr02_5/p3 